\title{
МОРФОЛОГОАНАТОМИЧЕСКОЕ СТРОЕНИЕ ЛИСТЬЕВ ИРГИ КОЛОСИСТОЙ (AMELANCHIER SPICATA (LAM.) C. KOCH)
}

\author{
( Дроздова И.Л. ${ }^{1}$, Трембаля Я.С. ${ }^{1}$, Минакова Е.И. ${ }^{1}$, Орьнбасарова К.К. ${ }^{2}$, Омиралиев М.А. ${ }^{2}$
}

\author{
${ }^{1}$ Курский государственный медицинский уиверситет (КГМУ) \\ Россия, 305041, Курская область, г. Курск, ул. К. Маркса, д. 3 \\ ${ }^{2}$ Южно-Казахстанская медицинская академия (ЮКМА) \\ Казахстан, Южно-Казахстанская область, г. Шымкент, пл. Аль-Фараби, д. 1/1
}

\begin{abstract}
Представители семейства розоцветные (Rosaceae) являются одними из широко распространенных среди отечественной флоры. Среди розоцветных - много официнальных лекарственных видов, пищевых и декоративных растений. Одним из представителей данного семейства является ирга колосистая (Amelanchier spicata (Lam.) C. Koch). В России и Казахстане данный вид давно выращивается как декоративное и пищевое растение. В научной медицине ирга колосистая в настоящее время не применяется. Не утверждена фармакопейная статья для этого растения. Для внедрения в научную медицину необходимо разработать показатели подлинности и провести исследование морфологоанатомических признаков строения листьев ирги колосистой.

Цель: изучение морфологических и анатомических признаков листьев ирги колосистой.

Материалы и методы. Морфологическое и анатомическое изучение листьев ирги колосистой проводили на свежем, воздушно-высушенном и фиксированном растительном материале. Для установления диагностических признаков сырья использовали общие фармакопейные статьи Государственной фармакопеи Российской Федерации XIV издания и Государственной фармакопеи Республики Казахстан.

Результаты. Впервые проведено морфологическое и анатомическое изучение листьев ирги колосиситой.

Заключение. Впервые выявлена совокупность макро- и микродиагностических признаков, которые могут быть использованы для определения подлинности лекарственного растительного сырья при разработке нормативной документации на листья ирги колосистой по разделам «Внешние признаки» и «Микроскопические признаки».

Ключевые слова: ирга колосистая; Amelanchier spicata (Lam.) C. Koch; листья; морфологические признаки; анатомические признаки; идентификация растительного сырья.
\end{abstract}

Дроздова Ирина Леонидовна - д-р фарм. наук, профессор кафедры фармакогнозии и ботаники, KГMУ, г. Kypcк. ORCID iD: 0000-0002-2231-2772. E-mail: irina-drozdova@yandex.ru (автор, ответственный за переписку)

Трембаля Янина Станиславовна - канд. биол. наук, доцент кафедры фармакогнозии и ботаники, КГМУ, г. Курск. ORCID iD: 0000-0001-6651-7940. E-mail: ya.trembal@yandex.ru

Минакова Евгения Игоревна - студентка, КГМУ, г. Курск. E-mail: evgenytraveler@mail.ru

Орынбасарова Кульпан Кенжебаевна - канд. фарм. наук, и.о. профессора кафедры фармакогнозии, ЮКМА, г. Шымкент. ORCID iD: 0000-0002-2610-9261. E-mail: kulpan ok@mail.ru

Омиралиев Мурат Адиханович - канд. фарм. наук, и.о. доцента кафедры фармакогнозии, ЮКМА, г. Шымкент. ORCID iD: 0000-0003-4003-1816. E-mail: murat.omiraliev@mail.ru

Лекарственные растения и фитопрепараты, получаемые из них, имеют многовековую историю применения для лечения и профилактики практически всех заболеваний человека [18]. Это связано с целым рядом особенностей фитотерапии: при широком спектре фармакологической активности и эффективности фитопрепараты характеризуются малой токсичностью, что, в свою очередь, дает возможность использования их в течение длительного времени для лечения и профилактики многих хронических (в т.ч. социально значимых) заболеваний. Современный принцип применения лекарственного растительного сырья в медицине уже не носит чисто эмпирический характер, а обязательно имеет научное обоснование и учитывает содержание биологически активных веществ (БАВ) и их биологическую активность [18]. Следует отметить, что ассортимент фитопрепаратов постоянно расширяется за счет изучения химического состава, фармакологических свойств и внедрения в научную медицину новых лекарственных растений [16]. Так, данные литературы и результаты собственных исследований показывают, что многие представители флоры Центральной России, издавна используемые в народной медицине, содержат различные группы биологически активных веществ (полисахариды, фенольные соединения, аминокислоты, минеральные элементы и др.) и обладают разносторонними видами фармакологической активности, что позволяет считать их потенциальными перспективными сырьевыми источниками для внедрения в научную медицину $[2,3,9,10,11$, $12,13]$.

Широко распространенными представителями флоры стран СНГ являются растения семейства розоцветные (Rosaceae). Среди розоцветных много официнальных лекарственных видов, а также пищевых и декоративных расте- 
ний $[4,5,19]$. Причем до настоящего времени многие виды этого семейства используются только в народной медицине ввиду их недостаточной изученности.

Одним из таких представителей является ирга колосистая или «коринка» (Amelanchier spicata (Lam.) C. Koch) - листопадный кустарник или небольшое деревце высотой до 5 м с густой овальной кроной, образованной многочисленными побегами. Скелетные ветви и старые побеги имеют темно-серый цвет, молодые - красновато-коричневый. Листья простые, черешковые, яйцевидной формы длиной до 5 см, при распускании бело-войлочные, летом - темнозеленые сверху и светло-зеленые снизу. Прилистники линейные, рано опадают. Цветки белые или розоватые, собраны по 4-10 в короткие, плотные, прямостоячие кисти. Плоды яблоковидные, округлые диаметром до 0,9 см, в начале созревания красные, в полной зрелости - темнофиолетовые, почти черные, с обильным восковым сизым налетом, сладковатые, съедобные [8, 19] (рис. 1). Родиной ирги колосистой является восточная часть Северной Америки [8, 17, 19, 20, 27]. В России и странах СНГ данный вид давно введен в культуру и широко выращивается в садах как плодовое и в парках как декоративное (в одиночных и групповых посадках) растение $[15,19,21,23]$. Данный вид легко дичает и может встречаться в разреженных лесах, у дорог, на опушках и полянах. Ирга является зимостойким, относительно засухоустойчивым растением, быстро растет, легко размножается с помощью семян, отводков, черенков и делением куста $[8,19]$, что говорит о достаточной сырьевой базе и позволяет считать данный вид перспективным растением для внедрения в научную медицину.

В России и странах СНГ (в т.ч. в Казахстане) в настоящее время ирга колосистая не является официнальным видом; однако ее плоды широко используются в пищу в свежем и переработан-

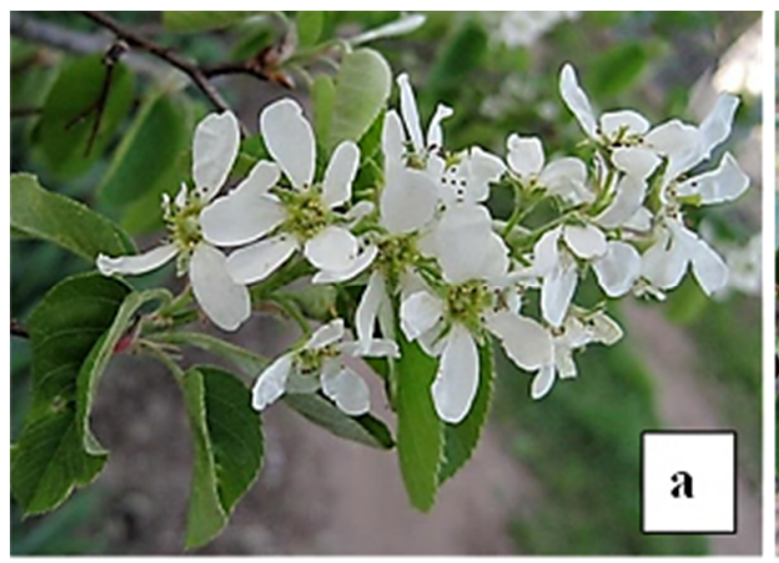

ном виде: из них готовят пастилу, желе, вино, а высушенные плоды в быту называют «коринкой» $[8,15]$. При изучении состава плодов ирги колосистой и еще 5 других видов ирги (ольхолистной, кроваво-красной, гладкой, канадской и обильно цветущей) было установлено наличие антоцианов в качестве основных компонентов (цианидин-3-галактозид, цианидин-3-глюкозид и цианидин-3-арабинозид) [28]. Данные литературных источников показывают, что в химическом отношении ирга колосистая практически не изучена, но изучался состав других близкородственных видов, а именно, ирги овальнолистной, в которой установлено наличие различных классов БАВ: листья содержат фенолкарбоновые кислоты, плоды - флавоноиды, антоцианы, органические кислоты; кроме того, обнаружены полисахариды, витамины Р и С, дубильные вещества $[4,5]$. В народной медицине ирга овальнолистная используется в качестве вяжущего средства, при болезнях органов пищеварения [5]; экспериментально установлена антибактериальная активность ее экстракта $[4,5]$.

Возможность использования ирги колосистой в научной медицине вызывает необходимость морфологоанатомического изучения и установления диагностических признаков лекарственного растительного сырья. До настоящего времени было изучено только анатомическое строение плодов и семян ирги колосистой [20].

Цель работы: изучение морфологических и анатомических признаков листьев ирги колосистой.

\section{МАТЕРИАЛЫ И МЕТОДЫ ИССЛЕДОВАНИЯ}

Объектом исследования служили листья ирги колосистой. Место заготовки образцов сырья - Курская область; фаза заготовки - окончание цветения - начало плодоношения.

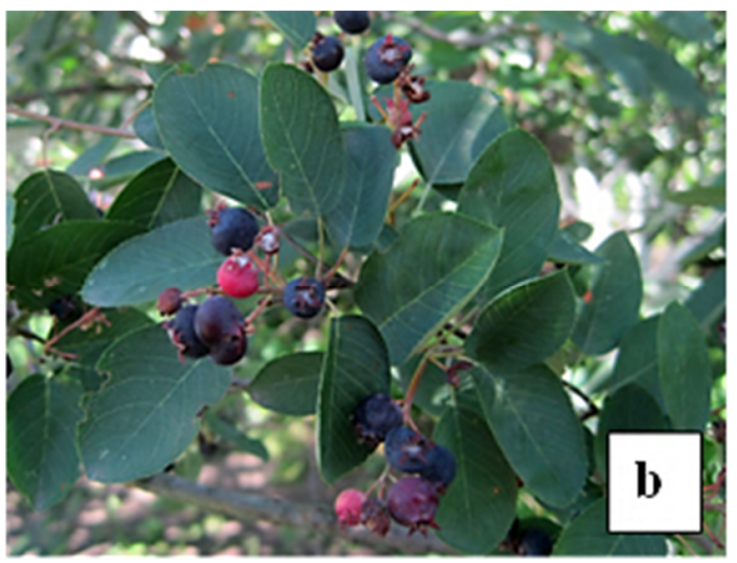

Рис. 1. Внешний вид ирги колосистой (a - период цветения, $\mathrm{b}$ - период плодоношения).

Fig. 1. The appearance of Amelanchier spicata (Lam.) C. Koch ( $\mathrm{a}$ - flowering period, $\mathrm{b}$ - fruiting period). 
Морфологическое и анатомическое изучение листьев ирги колосистой проводили на свежем, воздушно-высушенном и фиксированном в спирто-водо-глицериновой смеси (1:1:1) сырье $[14,25,26]$. Для установления диагностических признаков сырья использовали общие фармакопейные статьи Государственной фармакопеи Российской Федерации XIV издания (ОФС.1.5.1.0003.15 «Листья» и ОФС.1.5.3.0003.15 «Техника микроскопического и микрохимического исследования лекарственного растительного сырья и лекарственных растительных препаратов») [7] и Государственной фармакопеи Республики Казахстан (статья «Техника микроскопического и микрохимического исследования лекарственного растительного сырья») [6]. Препараты исследовали при помощи светового микроскопа «Биолам Ломо». Для получения микрофотографий использовали цифровую фотокамеру; полученные изображения редактировали с использованием графической программы «Adobe Photoshop CC ×64». Описываемые анатомические признаки приведены в соответствии с терминологией И.А. Самылиной и О.Г. Аносовой [22].

\section{РЕЗУЛЬТАТЫ ИССЛЕДОВАНИЯ И ИХ ОБСУЖДЕНИЕ}

Проведенные исследования позволили нам впервые выявить и описать внешние (морфологические) и микроскопические признаки листьев ирги колосистой.

Внешние (морфологические) признаки листа. Листья цельные или могут быть частично измельченные, простые, есть черешок, прилистники отсутствуют. Листовая пластинка со- ставляет в длину 2,5-5,0 см, в ширину 2,0-3,5 см. Листья имеют эллиптическую или широкоэллиптическую форму. Верхушка листа заостренная, основание округлое или широко клиновидное, край мелкопильчатый. Жилкование перистое. Листовая пластинка почти голая с верхней стороны, с нижней стороны имеются волоски. Черешок листа имеет в поперечном сечении округлую форму; длина до 2,0 см. Цвет листовой пластинки - темно-зеленый с верхней стороны, светло-зеленый с нижней стороны. Снизу листа хорошо видны светло-зеленые выступающие жилки (рис. 2). Под лупой (10×) или стереомикроскопом $(16 \times)$ видно, что листовая пластинка с нижней стороны, а также черешок опушены волосками. Запах слабый. Вкус водного извлечения слегка горьковатый.

Микроскопические признаки листа. Клетки верхнего эпидермиса листа ирги колосистой паренхимной формы, прямо- или слегка извилистостенные (рис. 3а); клетки нижнего эпидермиса имеют более извилистые стенки с хорошо выраженной складчатостью кутикулы (рис. 3b, 3c). Устьичный аппарат аномоцитного типа строения; устьица эллиптической формы расположены на нижнем эпидермисе, погруженные; замыкающие клетки окружены 4-6 побочными клетками (рис. 3b, 3c). На листовой пластинке (особенно с нижней стороны) имеются трихомы - простые одноклеточные толстостенные, извивающиеся и закручивающиеся волоски с гладкой поверхностью, которые встречаются и в других видах семейства Rosaceae (рис. 3d). Meзофилл содержит кристаллические включения оксалата кальция - друзы (рис. Зе). Жилки листа окружены кристаллоносной обкладкой оксалата кальция (рис. 3f).

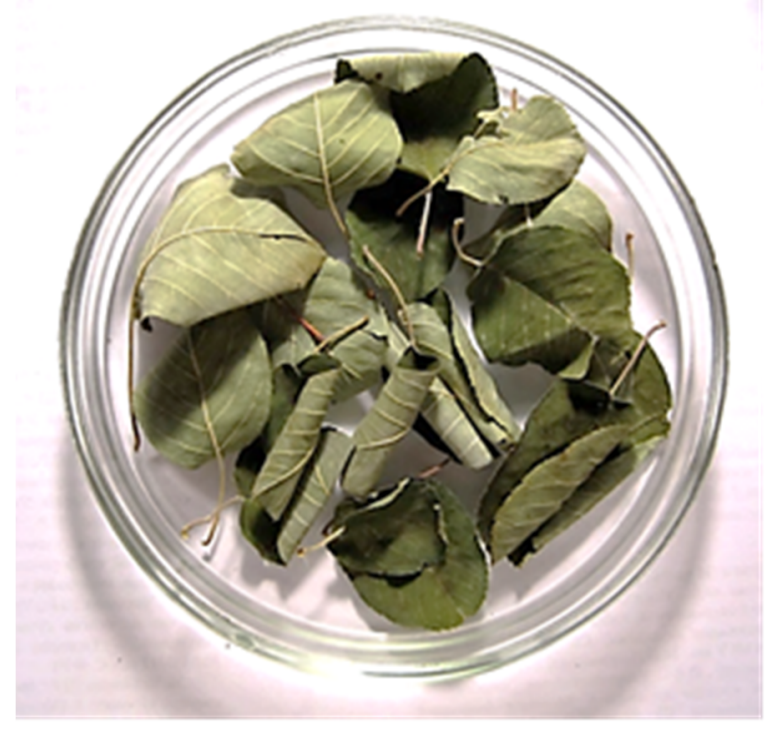

Рис. 2. Лекарственное сырье - листья ирги колосистой.

Fig. 2. Medicinal raw material - the leaves of Amelanchier spicata (Lam.) C. Koch. 

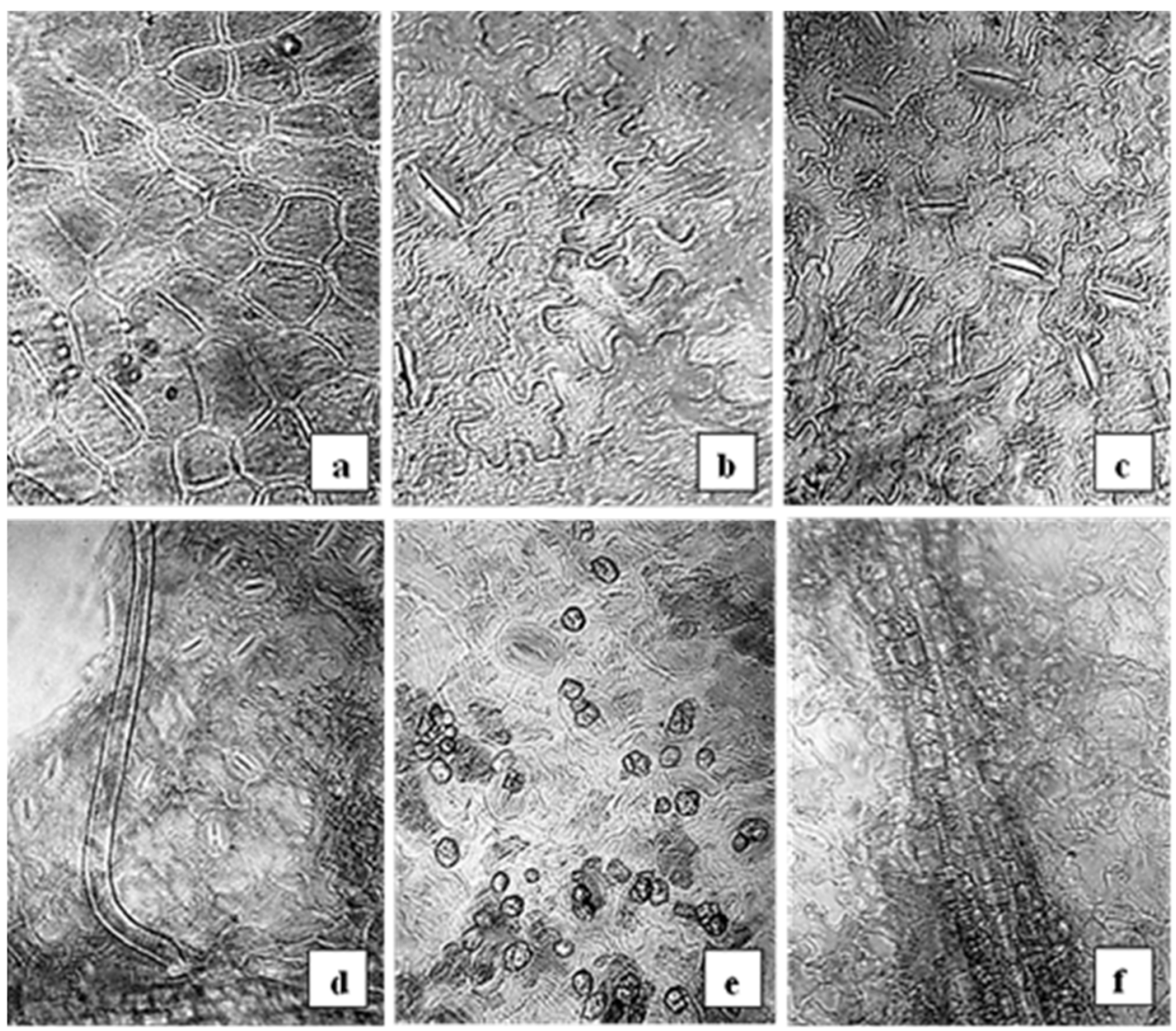

Рис. 3. Фрагменты эпидермиса листа $(10 \times 8,10 \times 20,10 \times 40)$

Примечание: a, b, с - клетки верхнего (a) и нижнего (b, c) эпидермиса, с - складчатость кутикулы, устьица аномоцитного типа; $\mathrm{d}$ - простые одноклеточные толстостенные волоски с гладкой поверхностью; е - друзы оксалата кальция; f - жилка с кристаллоносной обкладкой.

Fig. 3. Fragments of leaf epidermis $(10 \times 8,10 \times 20,10 \times 40)$

Note: a, b, c - cells of the upper (a) and lower (b, c) epidermis, c - folding cuticle, stomata of anomocyte type; $d$ - simple single-celled thick-walled hairs with a smooth surface, $\mathrm{e}$ - calcium oxalate druses; $\mathrm{f}$ - vein with crystalliferous sheath.

Микроскопические признаки черешка. Черешок в поперечном сечении имеет округлую форму (рис. 4а). Покровной тканью является однослойный эпидермис с хорошо выраженной складчатостью кутикулы (рис. 4b). Устьица встречаются редко, имеют аномоцитный тип строения, форма устьичного аппарата - эллиптическая, количество побочных клеток от 4 до 6 (рис. 4c). Черешок опушен многочисленными простыми волосками, характерными для листа ирги колосистой (рис 4a, 4d). Колленхима уголкового типа строения, залегает в 2-4 слоя под эпидермисом (рис. 4a, 4d). Проводящие ткани расположены в центре черешка в виде одного крупного закрытого коллатерального пучка (рис. 4а). В мезофилле встречаются включения оксалата кальция в виде призматических кристаллов или друз (рис. 4е, 4f).

Результаты проведенных исследований позволили установить в листьях ирги колосистой признаки, характерные и для других представителей семейства розоцветные, что согласуется с данными литературных источников [1, 22, 24]. Кроме того, установлена совокупность отличительных признаков, позволяющих проводить идентификацию лекарственного растительного сырья листьев ирги колосистой.

Таким образом, на основании настоящей работы можно сделать следующие выводы:

1. Впервые проведено морфологическое и анатомическое изучение листьев ирги колосиситой.

2. Впервые установлена совокупность макрои микроскопических признаков, которые позволяют достоверно проводить диагностику подлинности растительного сырья при разработке нормативной документации на листья ирги колосистой по разделам «Внешние признаки» и «Микроскопические признаки».

\section{КОНФЛИКТ ИНТЕРЕСОВ}

Авторы декларируют отсутствие явных и потенциальных конфликтов интересов, связанных с публикацией настоящей статьи. 


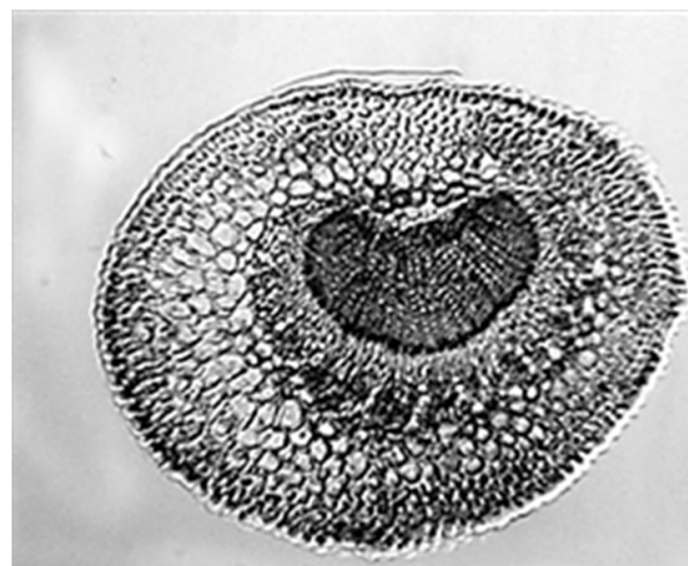

$\mathbf{a}$
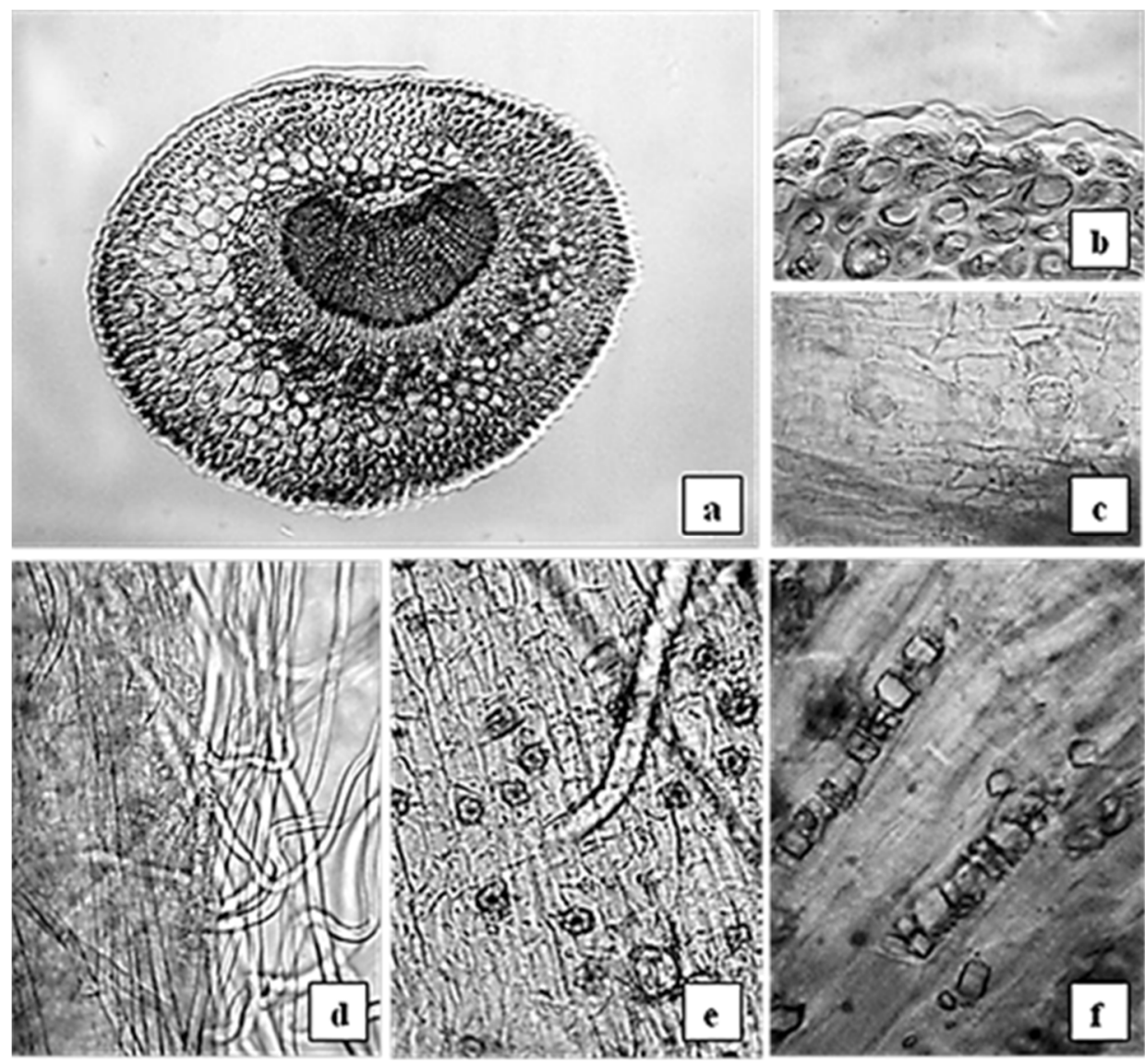

Рис. 4. Фрагменты черешка $(7 \times 8,10 \times 20,10 \times 40,15 \times 40)$.

Примечание: a - фрагмент поперечного среза черешка; b - складчатость кутикулы, уголковая колленхима; с - устьица аномоцитного типа; d - простые одноклеточные толстостенные волоски с гладкой поверхностью; е - друзы оксалата кальция; f - призматические кристаллы оксалата кальция.

Fig. 4. Fragments of petiole $(7 \times 8,10 \times 20,10 \times 40,15 \times 40)$.

Note: a - fragment of petiole cross-section; $\mathrm{b}$ - folding cuticle, corner colenchyma; $\mathrm{c}$ - stomata of anomocyte type; $\mathrm{d}$ - simple singlecelled thick-walled hairs with a smooth surface, $\mathrm{e}$ - druses of calcium oxalate; $\mathrm{f}$ - prismatic crystals of calcium oxalate.

\section{ЛИЧНЫЙ ВКЛАД АВТОРОВ}

Дроздова И.Л. - разработка концепции и дизайна исследования, сбор растительного материала для анализа, проведение анатомических исследований, описание микродиагностических признаков, анализ полученных результатов, написание рукописи и окончательное утверждение ее для публикации. Трембаля Я.С. - участие в разработке концепции и дизайна исследования, сбор растительного материала для анализа, проведение анатомических исследований, описание микродиагностических признаков, анализ полученных результатов, участие в написании рукописи и окончательном утверждении ее для публикации. Минакова Е.И. - сбор растительного материала для анализа, участие в проведении анатомических исследований и обработке полученных результатов, участие в описании микродиагностических признаков. Орынбасарова К.К. - участие в разработке концепции и дизайна исследования, участие в описании микродиагностических признаков и анализе полученных результатов, участие в написании рукописи и окончательном утверждении ее для публикации. Омиралиев М.А. - участие в разработке концепции и дизайна исследования, участие в описании микродиагностических признаков и анализе полученных результатов, участие в написании рукописи и окончательном утверждении ее для публикации.

\section{ИСТОЧНИКИ ФИНАНСИРОВАНИЯ}

Авторы заявляют об отсутствии финансирования.

\section{СООТВЕТСТВИЕ ПРИНЦИПАМ ЭТИКИ}

В данной работе одобрение этического комитета не требовалось.

\section{ЛИТЕРАТУРA/REFERENCES}

1. Бубенчикова В.Н., Дроздова И.Л. Земляника лесная. Курск: КГМУ, 2005. 128 с. [Bubenchikova V.N., Drozdova I.L. Wild strawberries. Kursk: KSMU, 2005. 128 p. (in Russ.)]

2. Бубенчикова В.Н., Дроздова И.Л. Разработка показателей качества листьев земляники лесной. Фармация. 2002; 6:16 [Bubenchikova V.N., Drozdova I.L. Development of indicators of quality of wild strawberry leaves. Farmatsiya. 2002; 6:16 (in Russ.)]

3. Бубенчикова В.Н., Дроздова И.Л. Фенольные соединения и полисахариды листьев Fragaria 
vesca L. Растительные ресурсы. 2003; 39(4):94-98 [Bubenchikova V.N., Drozdova I.L. Phenolic compounds and polysaccharides of the leaves of Fragaria vesca L. Rastitel'nyye resursy. 2003; 39(4):94-98 (in Russ.)]

4. Буданцев А.Л., под ред. Растительные ресурсы России: Дикорастущие иветковые растения, их компонентный состав и биологическая активность. Том. 2. Семейства Actinidiaceae-Malvaceae, Euphorbiaceae-Haloragaceae. Санкт-Петербург, Москва: Товарищество научных изданий КМК, 2009. 513 c. [Budantsev A.L., editor Plant resources of Russia: Wild flowering plants, their component composition and biological activity. Vol. 2. Families of Actinidiaceae-Malvaceae, Euphorbiaceae-Haloragaceae. Saint-Petersburg, Moscow: Tovarishchestvo nauchnykh izdaniy KMK, 2009. 513 p. (in Russ.)]

5. Буданцев А.Л., Лесиовская Е.Е., под ред. Дикорастущие полезные растения России. СанктПетербург: Изд-во СПХФА, 2001. 663 с. [Budantsev A.L., Lesiovskaya E.E., editors Wild useful plants of Russia. Saint-Petersburg: Izdatelstvo SPKHFA, 2001. 663 p. (in Russ.)]

6. Государственная фармакопея Республики Казахстан. Т. 1. Алматы: Издательский дом «Жибек жолы», 2008. 592 с. [State Pharmacopoeia of the Republic of Kazakhstan. Vol. 1. Almaty: Izdatel'skiy dom «ZHibek zholy», 2008. 592 p. (in Russ.)]

7. Государственная фармакопея Российской Федераuии. XIV издание. Том II. Москва: Федеральная электронная медицинская библиотека [State Pharmacopoeia of the Russian Federation. XIV edition. Vol. II. Moscow: Federal electronic medical library (in Russ.)] URL: http://femb.ru/femb/pharmacopea.php

8. Губанов И.А., Киселёва К.В., Новиков В.С., Тихомиров В.Н. Иллюстрированный определитель растений Средней России. Том 2: Покрытосеменные (двудольные: раздельнолепестные). Москва: Товарищество научных изданий КМК, Институт технологических исследований, 2003. 665 с. [Gubanov I.A., Kiselyova K.V., Novikov V.S., Tikhomirov V.N. Illustrated determinant of plants in Central Russia. Volume 2: Angiosperms (dicotyledons: choripetalae). Moscow: Tovarishchestvo nauchnykh izdaniy KMK, Institut tekhnologicheskikh issledovaniy, 2003. 665 p. (in Russ.)]

9. Дроздова И.Л. Выделение и химическое изучение полисахаридов травы донника рослого (Melilotus altissimus Thuill.). Вестник Воронежского государственного университета. Серия: Химия. Биология. Фармация. 2004; 1:173-175 [Drozdova I.L. Isolation and chemical study of grass polysaccharides Melilotus altissimus Thuill. Vestnik Voronezhskogo gosudarstvennogo universiteta. Seriya: Khimiya. Biologiya. Farmatsiya. 2004; 1:173-175 (in Russ.)]

10. Дроздова И.Л., Денисова Н.Н. Изучение аминокислотного состава травы короставника полевого. Традиционная медицина. 2012; 4(31):49-51 [Drozdova I.L., Denisova N.N. The study of the amino acid composition of grass Knautia arvensis (L.) Coult. Traditsionnaya meditsina. 2012; 4(31):49-51(in Russ.)]
11. Дроздова И.Л., Денисова Н.Н. Элементный состав травы короставника полевого Knautia arvensis (L.) Coult. Химия растительного сырья. 2013; 4:135-139 [Drozdova I.L., Denisova N.N. The elemental composition of the grass Knautia arvensis (L.) Coult. Khimiya rastitel'nogo syr'ya. 2013; 4:135-139 (in Russ.)]

12. Дроздова И.Л., Лупилина Т.И. Аминокислотный состав травы икотника серого. Вестник Воронежского государственного университета. Серия: Химия. Биология. Фармация. 2015;1:125-128 [Drozdova I.L., Lupilina T.I. The amino acid composition of berteroa incana herb. Proceeding of Voronezh State University. Series: Chemistry. Biology. Pharmacy. 2015; 1: 125-128 (in Russ.)]

13. Дроздова И.Л., Лупилина Т.И. Изучение состава фенольных соединений травы икотника серого методом ВЭЖХ. Сорбционные и хроматографические процессьь. 2013; 13(6):891-895 [Drozdova I.L., Lupilina T.I. The study of phenolic connections of the Berteroa incana (L.) DC. above-ground part by HPLC. Sorbtsionnye i khromatograficheskie Protsessy. 2013; 13(6):891-895 (in Russ.)]

14. Кахерская Ю.С., Горячкина Е.Г., Федосеева Г.М. Сравнительная морфолого-анатомическая характеристика сырья ортилии однобокой и грушанки круглолистной. Сибирский медицинский журнал (Иркутск). 2008; 76;1:84-86 [Kakherskaya Yu.S., Goryachkina E.G., Fedoseyeva G.M. Comparative morphological and anatomical characteristics of the raw materials Orthilia secunda and Pyrola rotundifolia. Sibirskiy meditsinskiy zhurnal (Irkutsk). 2008;76; 1:84-86 (in Russ.)]

15. Киселева К.В., Майоров С.Р., Новиков В.С. Флора средней полосы России. Москва: ЗАО «Фитон+»,2010. 544 c. [Kiseleva K.V., Mayorov S.R., Novikov V.S. Flora of Russia middle zone. Moscow: ZAO «Phyton+», 2010. 544 p. (in Russ.)]

16. Ковалева Л.Г., Сампиев А.М., Хочава М.Р., Никифорова Е.Б. Современное состояние и перспективы дальнейшего исследования плодов софоры японской. Научные ведомости Белгородского государственного университета. Серия: Медицина. Фармация. 2012; 22(141):163-170 [Kovaleva L.G., Sampiyev A.M., Khochava M.R., Nikiforova E.B. Current state and prospects of further research of Sophora japonica fruit. Nauchnyye vedomosti Belgorodskogo gosudarstvennogo universiteta. Seriya: Meditsina. Farmatsiya. 2012; 22(141):163-170 (in Russ.)]

17. Корунчикова В.В. Особенности биологии, экологии и перспективы использования интродуцированных видов ирги. Бюллетень ДНБС. 2013; 107:25-32 [Korunchikova V.V. The biology, ecology and perspectives of using the introduced shadberry species Amelanchier. Byulleten' DNBS. 2013; 107:25-32 (in Russ.)]

18. Ловкова М.Я., Рабинович А.М., Пономарева С.М., Бузук Г.Н., Соколова С.М. Почему растения лечат: Около 200 видов лекарственных растений с кратким биохимическим описанием. Москва: ЛЕНАНД, 2018. 228 с. [Lovkova M.Ya., Rabinovich A.M., Ponomareva S.M., Buzuk G.N., Sokolova S.M. Why plants are treated: About 200 species of 
medicinal plants with a brief biochemical description. Moscow: LENAND, 2018. 228 p. (in Russ.)]

19. Маевский П.Ф. Флора средней полосы европейской части России. Москва: Товарищество научных изданий КМК, 2014. 635 c. [Mayevskiy P.F. Flora of the middle zone of the European part of Russia. Moscow: Tovarishchestvo nauchnykh izdaniy KMK, 2014. 635 p. (in Russ.)]

20. Никитин А.А., Панкова И.А. Анатомический атлас полезных и некоторых ядовитых растений. Ленинград: Наука, 1982. 768 с. [Nikitin A.A., Pankova I.A. Anatomical Atlas of useful and some poisonous plants. Leningrad: Nauka, 1982. 768 p. (in Russ.)]

21. Полуянов А.В., Прудников Н.А. Сосудистыле растения Курской области. Курск: КГУ, 2005. 80 с. [Poluyanov A.V., Prudnikov N.A. Vascular plants of the Kursk region. Kursk: KSU, 2005. 80 p. (in Russ.)]

22. Самылина И.А., Аносова О.Г. Фармакогнозия. Аmлас: в 2-томах. Том 1. Москва: ГЭОТАР-Медиа, 2007. 192 c. [Samylina I.A., Anosova O.G. Pharmacognosy. Atlas: in 2 volumes. Vol. 1. Moscow: GEOTAR-Media, 2007. 192 p. (in Russ.)]

23. Семенютина А.В., Шилов Е.П. Интродукция видов рода Amelanchier Medik и перспективы их использования в многофункциональных лесонасаждениях. Известия нижневолжского агроуниверситетского комплекса. 2013; 3(31):1-4 [Semenyutina A.V., Shilov E.P. Introduction of species of the genus Amelanchier Medik and the prospects of their use in multifunctional forests. Izvestiya nizhnevolzhskogo agrouniversitetskogo kompleksa. 2013; 3(31):1-4 (in Russ.)]

24. Серебряная Ф.К., Геоня И.В., Алиева К.М. Сравнительное морфолого-анатомическое исследование вегетативных органов лабазника обыкновенного (Filipendula vulgaris Moench.) и лабазника вязолистного (Filipendula ulmaria (L.) Мaxim.), произрастающих на Северном Кавказе. Фармация $u$ фармакология. 2016; 4(5):63-80 [Serebryanaya F.K.,
Geonya I.V., Aliyeva K.M. Comparative morphological and anatomical study of vegetative organs of the Filipendula vulgaris Moench. and Filipendula ulmaria (L.) Maxim. native to the North Caucasus. Farmatsiya $i$ farmakologiya. 2016; 4(5):63-80 (in Russ.)] DOI: 10.19163/2307-9266-2016-4-5-63-80

25. Трембаля Я.С., Прокошева Л.И., Лапина Е.С. Анатомическое строение вегетативных органов астрагала нутового (Astragalus cicer L.). Фармация $u$ фармакология. 2014; 6(7):33-35 [Trembalya Ya.S., Prokosheva L.I., Lapina E.S. Anatomical structure of vegetative organs of Astragalus cicer L. Farmatsiya $i$ farmakologiya. 2014; 6(7):33-35 (in Russ.)] DOI:10.19163/2307-9266-2014-2-6(7)-33-35

26. Трембаля Я.С., Дроздова И.Л., Кузькина Э.Е. Анатомическое строение вегетативных органов герани лесной (Geranium sylvaticum L.). Международный научно-исследовательский журнал. 2018; 1-1(67):176-180 [Trembalya Ya.S., Drozdova I.L., Kuzkina E.E. Anatomical structure of vegetative organs of wood geranium (Geranium Sylvaticum L.). Mezhdunarodnyy nauchno-issledovatel'skiy zhurnal. 2018; 1-1(67):176-180 (in Russ.)]

27. Цвелёв Н.Н. О роде ирга (Amelanchier medik., Rosaceae) в Европейской России. Новости систематики высших растений. 2010; 42:174-177 [Tsvelyov N.N. On the genus amelanchier (Amelanchier medik., Rosaceae) in European Russia.. Novosti sistematiki vysshikh rasteniy. 2010; 42:174-177 (in Russ.)]

28. Чулков А.Н., Дейнека В.И., Дейнека Л.А., Степанова A.В. Антоцианы плодов шести видов Amelanchier sp. Научные ведомости Белгородского государственного университета. Серия Естественные науки. 2011; 15-2(104):209-215 [Chulkov A.N., Deyneka B.I., Deyneka L.A., Stepanova A.V. Anthocyanins of fruits of six species of Amelanchier sp. Nauchnyye vedomosti Belgorodskogo gosudarstvennogo universiteta. Seriya Estestvennyye nauki. 2011; 152(104):209-215 (in Russ.)]

Поступила в редакцию 01.06.2019

Подписана в печать 19.09.2019

Для цитирования: Дроздова И.Л., Трембаля Я.С., Минакова Е.И., Орынбасарова К.К., Омиралиев М.А. Морфологоанатомическое строение листьев ирги колосистой (Amelanchier spicata (Lam.) C. Koch). Курский научно-практический вестник «Человек и его здоровье». 2019; (3):79-86. DOI: 10.21626/vestnik/2019-3/11. 


\title{
MORPHOLOGICAL AND ANATOMICAL STRUCTURE OF AMELANCHIER SPICATA (LAM.)
}

\section{KOCH LEAVES}

\author{
○ Drozdova I.L. ${ }^{1}$, Trembalya Ya.S. ${ }^{1}$, Minakova E.I. ${ }^{1}$, Orynbasarova K.K. ${ }^{2}$, Omiraliev M.A. ${ }^{2}$ \\ ${ }^{1}$ Kursk State Medical University (KSMU) \\ 3, K. Marx St., Kursk, Kursk region, 305041, Russian Federation \\ ${ }^{2}$ South Kazakhstan Medical Academy (SKMA) \\ 1/1, Al-Farabi Sq., Shymkent, South Kazakhstan region, 160019, Republic of Kazakhstan
}

\begin{abstract}
Representatives of the family Rosaceae are ones of the most widespread among the domestic flora. Among Rosaceae there are many official medicinal species, food and decorative plants. One of the representatives of this family is Amelanchier spicata (Lam.) C. Koch. In Russia and Kazakhstan this species has long been grown as a decorative and food plant. In scientific medicine Amelanchier spicata (Lam.) C. Koch is not currently used since there is no approved pharmacopeial monograph for this plant. The introduction into scientific medicine requires to develop indicators of authenticity and to conduct a study of morphological and anatomical features of the structure of Amelanchier spicata (Lam.) C. Koch leaves.

Objective: to study the morphological and anatomical features of leaves of Amelanchier spicata (Lam.) C. Koch.

Materials and methods. Morphological and anatomical study of Amelanchier spicata (Lam.) C. Koch leaves was carried out on fresh, air-dried and fixed plant material. The common Pharmacopoeia articles of both the XIV edition State Pharmacopoeia of Russian Federation and the State Pharmacopoeia of the Republic of Kazakhstan were used to establish the diagnostic features of raw materials.

Results. For the first time the morphological and anatomical study of Amelanchier spicata (Lam.) C. Koch leaves was carried out.

Conclusion. For the first time a set of macro- and microdiagnostic features that can be used to determine the authenticity of medicinal plant raw materials in the development of regulatory documentation for the leaves of Amelanchier spicata (Lam.) C. Koch. in the sections «External signs» and «Microscopic signs» was revealed.

Keywords: Amelanchier spicata (Lam.) C. Koch; leaves; morphological features; anatomical features; raw material identification.
\end{abstract}

Drozdova Irina L. - Doctor of Pharmacy, Professor of Pharmacognosy and Botany Department, KSMU, Kursk, Russian Federation. ORCID iD: 0000-0002-2231-2772. E-mail: irina-drozdova@yandex.ru (correspondence author)

Trembalya Yanina S. - PhD in Biology, Associate Professor of Pharmacognosy and Botany Department, KSMU, Kursk, Russian Federation. ORCID iD: 0000-0001-6651-7940. E-mail: ya.trembal@yandex.ru

Minakova Evgenia I. - Student, KSMU, Kursk, Russian Federation. E-mail: evgenytraveler@mail.ru

Orynbasarova Kulpan K. - PhD in Pharmacy, Professor of Pharmacognosy and Botany Department, SKMA, Shymkent, Kazakhstan. ORCID iD: 0000-0002-2610-9261. E-mail: kulpan ok@mail.ru

Omiraliev Murat A. - PhD in Pharmacy, Associate Professor of Pharmacognosy and Botany Department, SKMA, Shymkent, Kazakhstan. ORCID iD: 0000-0003-4003-1816. E-mail: $\underline{\text { murat.omiraliev@mail.ru }}$

\section{CONFLICT OF INTEREST}

The authors declare the absence of obvious and potential conflicts of interest related to the publication of this article.

\section{SOURCE OF FINANCING}

The authors state that there is no funding for the study.

\section{CONFORMITY WITH THE PRINCIPLES OF ETHICS}

In this work the approval of the ethics committee was not required

\section{AUTHORS CONTRIBUTION}

Drozdova I.L. - development of the concept and design of the study, collection of plant material for analysis, anatomical studies, description of microdiagnostic features, analysis of the results, writing the manuscript and its final approval for publication. Trembalya Ya.S. - participation in the development of the concept and design of the study, collection of plant material for analysis, anatomical studies, description of microdiagnostic features, analysis of the results, participation in writing the manuscript and its final approval for publication. Minakova E.I. - collection of plant material for analysis, participation in anatomical studies and processing of the results, participation in the description of microdiagnostic features. Orynbasarova K.K. - participation in the development of the concept and design of the study, participation in the description of microdiagnostic features and analysis of the results, participation in writing the manuscript and its final approval for publication. Omiraliev M.A. - participation in the development of the concept and design of the study, participation in the description of microdiagnostic features and analysis of the results, participation in writing the manuscript and its final approval for publication.

Received 01.06.2019 Accepted 19.09.2019

For citation: Drozdova I.L., Trembalya Ya.S., Minakova E.I., Orynbasarova K.K., Omiraliev M.A. Morphological and anatomical structure of Amelanchier spicata (Lam.) C. Koch leaves. Kursk Scientific and Practical Bulletin "Man and His Health". 2019 ; (3):79-86. DOI: 10.21626/vestnik/2019-3/11. 